\title{
EXPLORING THE M-LEARNING AS A FEEDBACK TOOL IN HIGHER EDUCATION
}

\author{
Dr. Karima Hussein ${ }^{1}$, Ms. Madeha Faiz Rana ${ }^{2}$ \\ ${ }^{1}$ Dar Al-Hekma University, Saudi Arabia, khussein@dah.edu.sa \\ ${ }^{2}$ Dar Al-Hekma University, Saudi Arabia, mrana@dah.edu.sa
}

\begin{abstract}
Mobile devices are playing an important role these days in education. Using mobile devices as an effective tool to promote learning could bring a prominent change. Mobile Learning is usually considered as the new tool in the education field for assisting teachers and students as it has expanded the options for the distance learning. Several studies have made attempts to assess the possible methods and the challenges related to the M-learning. This study investigates the effectiveness of M-learning for the undergraduate students in education, explores M-learning as a feedback tool and communication, and evaluates the current use of $\mathrm{E}$ Learning system. For the purpose of data collection, recent researches related to using mobile technologies in learning were reviewed. Also, a survey was conducted using the five-point Likert scale, and the sample involved students and teachers, both belonging to Dar Al-Hekma University, KSA, so that the views of students and teachers can be determined. This study focuses on using mobiles as the feedback tool for students belonging to the creative field especially after the last day of classes, while they are in printing houses and photo shooting. The survey discusses the acceptance of M-Learning as a useful tool that facilitates the learning activities among the students more quickly. Moreover, using mobile learning may increase the learning capabilities of the students and meet the expectations of teachers. The study has shown that using the mobile phone as a feedback tool can allow enhancing the learning among students when they are off campus. It is recommended that Dar Al-Hekma University should take the services of experts to develop the mobile phone application and then provide access to the teachers and the students for ensuring the provision of the quality of education. However, this would need some time and financial resources for the implementation.
\end{abstract}

Keywords: M-Learning, Higher Education, Feedback

\section{INTRODUCTION}

The study investigates using the mobile as a feedback tool in the creative field especially after the last day of classes till the submission day, photo shooting, in printing houses and during the summer internship. Also enhancing the quality of learning and teaching in general to meet students' expectation and improve access to learning for students off campus with taking the pros of mobile as a fixable tool in learning in how, where and when. Also investigate how best to use mobile technologies in the learning and teaching environment in 
Dar Al-Hekma University, Jeddah, Saudi Arabia.

\section{RESEARCH QUESTIONS}

Articles in The Chronicle of Higher Education and eLearning Magazine, as well as in blackboard website provide commentary on potential benefits and effectiveness of M-Learning. life?

RQ1: How is the mobile technology affecting the learning environment in higher education out campus

RQ2: Does Dar Al-Hekma University faculty and students need to use of mobile in learning?

RQ3: Do students and teacher use the current system application (blackboard) for communication?

RQ4: What are the common perceptions among current Dar Al-Hekma students (seniors and juniors) about the nature of M-Learning?

RQ5: Does the communication between the teacher and student will be more effective if they use mobile in learning?

RQ6: Does teacher be comfortable in using the m-learning in giving feedback more than the desktop computers beyond the classroom time?

RQ7: Does the m-learning will affect on the learning engagement especially during the final project and if the teacher in her/his professional development?

RQ8: How prepared are we in higher education to cope with, or take advantage of the m-learning?

\section{METHODOLOGY}

In this study, authors included the major components: a literature review, online quantitative survey, qualitative interviews (focus group), and case study of the current situation of Dar Al-Hekma University. Both students and faculty need to complete a survey about their experience. The survey utilized a five-point Likert scale comparing their attitudes to the m-learning systems for both teacher and students to measure the effectiveness of the current ways for getting/giving feedback outside the campus. Focus groups with the faculty members who taught internship in the last summer and the faculty members who are currently teach sophomore and seniors (first and second semester).

The authors surveyed recent researches including mobile technology and elaborated mobile learning model in learning strategies to provide supportive secondary evidence. In our study, students and faculty need to complete a survey about their experience

\section{LITERATURE REVIEW}

We surveyed recent researches including mobile technology and elaborated mobile learning model in learning strategies.

To answer the research questions, we must assess the current state of student-teacher communication out campus (Dar Al-Hekma). Moreover consider the Saudi Arabia and especially Dar Al-Hekma University since it lags behind other parts of the world in several educational aspects.

People are using wireless technology more often because information retrieval, Chen, H.-R., \& Huang, H.-L. (2010) described that on their study for mobile learning, It is considered as the first study focusing on the designed mobile knowledge management learning system with the intention of promoting the learners. It could be analyzed by the achievements of students; the investigational group has relatively significant effect for adopting learning system for controlling the traditional classroom lectures. Evaluating it through questionnaire survey, the investigational outcomes indicated that supposed easy to utilize the positivity of calculated usefulness by means of the learners, supposed usefulness is the learning process must guide an important feature for students' enthusiasm.

\section{REAL-TIME FEEDBACK TOOL}

Aagard, H., Bowen, K., \& Olesova, L. (2010) described how smartphones are perfect tool for providing real time response and evaluation for improving teaching and learning results, this became possible through $\mathrm{M}$ learning with respect to the different and popular social tools. The reaction of students are directly organized and proposed through Hotseat in campus. Entry to Hotseat is approved by the student's standard university login, which is based on the course enrollment. The factors of social tools allow fast community building in the course. 


\section{MOBILE LEARNING DEFINITION IN HIGHER EDUCATION:}

Huang, Y.-M., Hwang, W.-Y., \& Chang, K.-E. (2010), mention the definition of mobile learning as "the category of learning culture that lays in educational surroundings and spaces, takes account of mobility of equipment's mobility, with respect to learners and learning".

Also, many researchers have defined mobile learning from different dimensions. Mobile learning has one assumption that learners can move continually with mobile devices and possible wireless connection. Mobile devices also could provide meaningful assistance to users' work, study and entertainment. For education, the context, learning process and the outcomes should be considered with an extension to the outside of the classrooms or lecture halls. The paper "Defining Mobile Learning: Redesign Higher Education Landscape" written by El-Hussein, M. O. M., \& Cronje, J. C. (2010) attempted to interpret the meaning of mobile learning in higher education by applying mobile concepts and characteristics as various elements of the mobile learning experience.

Specifically there are many investigators that describe mobile education in a particular extent. Mobile learning has one assumption that learners can move continually with mobile devices and possible wireless connection. The m-learning devices can provide meaningful assistance, to the users work, study as well as activity. In concentration to the educational context, the process of learning and the outcomes must be considered as an extension to the outside of the lecture halls or classrooms. Huang, Y.-M., Hwang, W.-Y., \& Chang, K.-E. (2010).

\section{Current System application (Blackboard):}

The learning, management systems like Blackboard (Blackboard LearnTM, 2009) are at the front of topical technology that advances in Higher Education. Heirdsfield, A., Walker, S., Tambyah, M., \& Beutel, D. (2011) stated that Blackboard was adopted by Queensland University of Technology as an online learning management system for both on-campus and distance learners. The contact of learning management systems is just like the boundaries between distance education as well as the campus -based experiences that have been distorted and are being replaced through the hybrid modes or we can say by distributed learning, by means of the technology mediated instructions as the norms, Masi, A., \& Winer, L. (2005).

According to Kinash, Brand \& Mathew, (2012) the new technologies that have the potential to enhance the way of teachers teach and learners learn is M-learning. Also Levine, A., \& Sun, J. C. (2003) supported that by explaining how M-learning offers a highly interactive medium that can be customized to meet the personal needs of students in accordance to their learning material.

The reason of using m-learning and avoiding the use of learning management systems like Blackboard has been recognized as a key limitation of these systems Bradford, P., Porciello, M., Balkon, N., \& Backus, D. (2007). As well as, the teachers do not have time for motivating themselves to become expert users of online systems thus limiting the use of innovative pedagogies. In accordance with Christie, M., \& Garrote Jurado, R. (2009) the obstacles in the use of innovations are understandable and teachers require to be influenced with the value of learning management systems, if they want to realize their prospective.

\section{OPPORTUNITIES FOR TEACHERS AND STUDENTS}

The focus on M-learning started in the beginning of $21^{\text {st }}$ century. In April 2000 issues regarding Computers and Education, Sharples, M. (2000) studied the possibility of new designs in mobile technology that enhances lifelong learning programs by continuing the developed educational opportunities. Numerous ideas are raised in the article are still developing and are interested in today's M-Learning.

The articles evaluate mobile learning technology is increasing. Gomez, S. (2007) has stated the ways of lectures and lessons to be conveyed through mobile technology. By passing the starting period of exercising and acclimation, comments on how teachers and learners experience the opportunities were measured. The students reported that they enjoy the ability to pause and segment lectures and for listening them on their own time. Abernathy, Donna J. (2001).

\section{DIFFERENCE IN M-LEARNING AND DESKTOP STUDY EQUIPMENTS}

McConatha, D., Praul, M., \& Lynch, M. J. (2008) offer one of the original appearances of technology and its effectiveness on future business approaches regarding to learning initiatives. Also Abernathy, Donna J. (2001) examine that M-learning alternatives are not essentially search to substitute PC as be-all equipment, excluding alternative notes that help supplement corporate learning goals with on the go equipment. 
Abernathy perfectly noted and suggested that the fledgling condition of Wi-Fi expertise must be a major tentative block in according to the future advancement. From 2002 to 2006 many studies instigate to appear which reported the indications of $\mathrm{M}$-learning knowledge expanding in the variety of learning environments. Investigators tackled with questions in the field of education and workers have had concerning to mobile learning, related to youth.

The researchers examined that how persistent mobile technology is nowadays as well as how is it expanding in the field. Wagner, E. D. (2005) stated that there is a difference between M-Learning and E-Learning. They disagreed with the devices and with the procedure by which education is been delivered with far more options to get today's students. The community of education including both teachers and students, inside or outside of campus has to realize the model of command and control of the devices, characteristic of conventional education structures, is being replaced by the chance of making learning extremely shared.

\section{ADVANTAGES OF M-LEARNING}

Thornton P. \& Houser C. (2005) reported about their research on data and opinions based on M-learning and its use in Japanese University. The country enabled mobile phones, PDAs as well as other portable media devices. The investigation evaluated results measures for classroom material by means of mobile technology, using e-mail and WAP technology (Wireless Application Protocol). This is necessary to note that in the Japanese University rates mobile phone strategies are far less expensive comparing to US, it allows many students to participate in M-Learning research and study. Outcomes of research were mainly revealing. Reactions of the students on new learning technology were positive. US caught more technological advancement in complex cell phone usage. The process must become even more eyecatching to the educational and business institutions for advancement of their learning surroundings.

Wagner, E. D. (2005) as well evaluates the recent state of mobile technology in America. Wagner mentions the examples in which mobile calculation has made important differences in people living style, for finding the survivors after 2004 Indian Ocean tsunami. M-Leaning is showing increase in dissemination at professional level as well. Pullchino, J. (2006) did a questionnaire survey on the group of organizations, he found that mobile technology and the devices were being used for audio and text content and wireless laptop was still the device of choice. However, I-Phone and cell phones were famous as well.

\section{ISSUES AND SOLUTIONS IN M-LEARNING}

Weekes, S. (2007) recommended that this is in actual the strength of M-learning. Fast development of wireless network technologies as well as the numerous mobile products enable public conveniently entrée for the formation of resources anywhere and at anytime. Therefore, the way of adapting information for delivering to mobile devices became a critical issue in the learning surroundings.

Kim, D., Rueckert, D., Kim, D.-J., \& Seo, D. (2013) approved the issues and agrees with the relevancy, he suggested more research for mobile learning studies. Moreover, the issue addressed in her study was about the classroom environment full of students with mobile devices came together to share content and messages, counteracting the assumptions that mobile phones have an isolation effect. Some other fields also did inquire in the effectiveness of mobile learning. Whisteled, N. (2004) reviewed the advent of Mlearning and mobile computing in the field of medicine. For medical students the classroom environment must be technologically sophisticated.

The hardware limitations of M-learning due to the devices used and software issues were enough for the students to offer somewhat lower ratings to M-learning approaches than in some other studies. However, the authors included this as supporting evidence that can help to improve the hardware and technological issues from the devices, as the devices can become increasingly ubiquitous in educational settings. Pullchino, J. (2006).

For addressing this concern, investigators have researched the issues in different ways and suggested many solutions. Yang, S.J.H., Chen, I., \& Shao, N., (2004) designed a worldwide entrée in the mechanism that provides a clear and flawless browsing experience for adapting the content based on XML/RDF, CC/PP and UAProf strategies. The suggested manner gives many content styles for making appropriate learning contents that can be displayed on miscellaneous learning devices.

\section{ANALYZE OF THE STUDENT SURVEY}

From the Blackboard Education Technology \& Services website the authors found that learning solutions with a mobile mindset engages today's students on the devices they know and love, any time, any place. Our solutions are built with a mobile first mentality to offer students an engaging and flexible experience to maximize learning. With evaluating the blackboard mobile application use by teachers and students, we 
found that descriptive statistics were used to measure the willingness of the use of the mobile application as a feedback tool while students are off campus. We distributed the survey through an e-mail sent to sophomore and senior students; we collected data $(N=30)$ from both sophomore $(n=20)$ and senior $(n=10)$ students currently enrolled in the visual communication department in Dar Al-Hekma University. 100\% percent of the respondents were female.

The analysis of closed questions from the two questionnaires consisted of assigning a code number to each closed question (e.g. Definitely not $=1$; Definitely $=5$ ).

\section{Do you currently use the Blackboard application?}

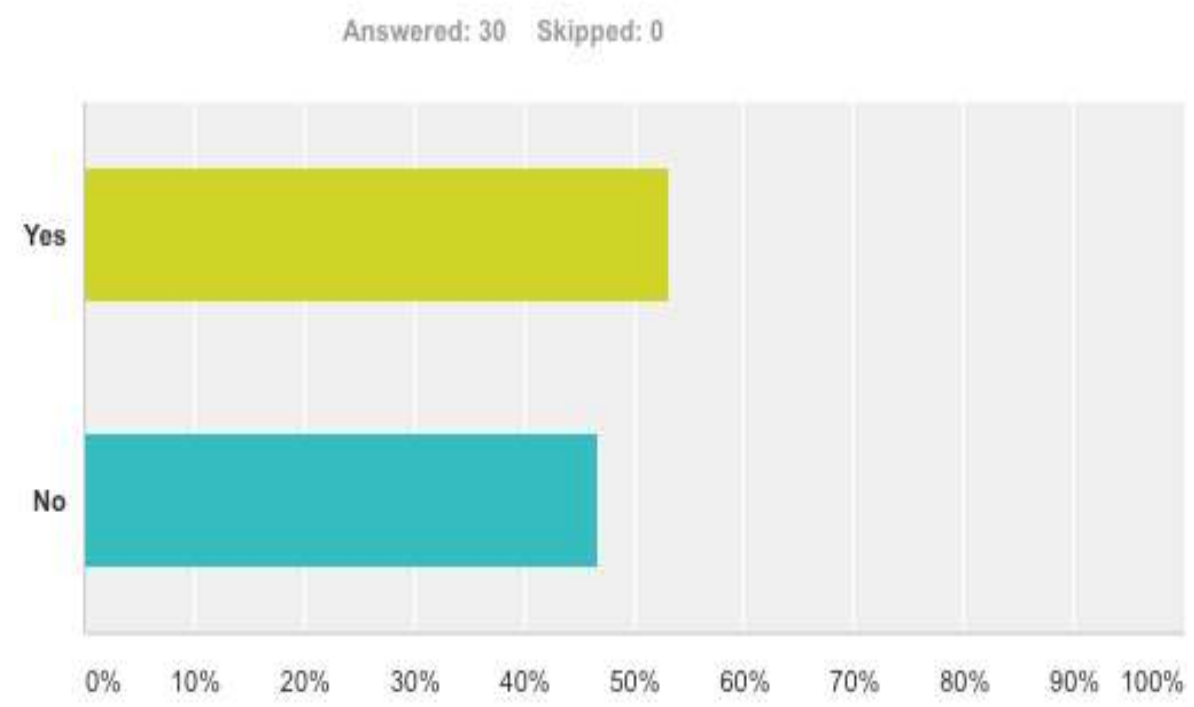

\begin{tabular}{l|ll}
\hline Answer Choices & Responses & \\
\hline Yes & $53.33 \%$ & 16 \\
\hline No & $46.67 \%$ & 14 \\
\hline Total Respondents: 30 & & \\
\hline
\end{tabular}

Table 1.1

Table 1.1: For the first question about the current usage of the Blackboard application via students' mobiles, $53.33 \%$ of the respondents use the blackboard application on their phones. Less than $47 \%$ said that they are not using the blackboard application in their courses. The significant result will appear when we discuss the faculty survey. 


\section{Would you like to use mobile phone in your class for the facilitation of the learning process?}

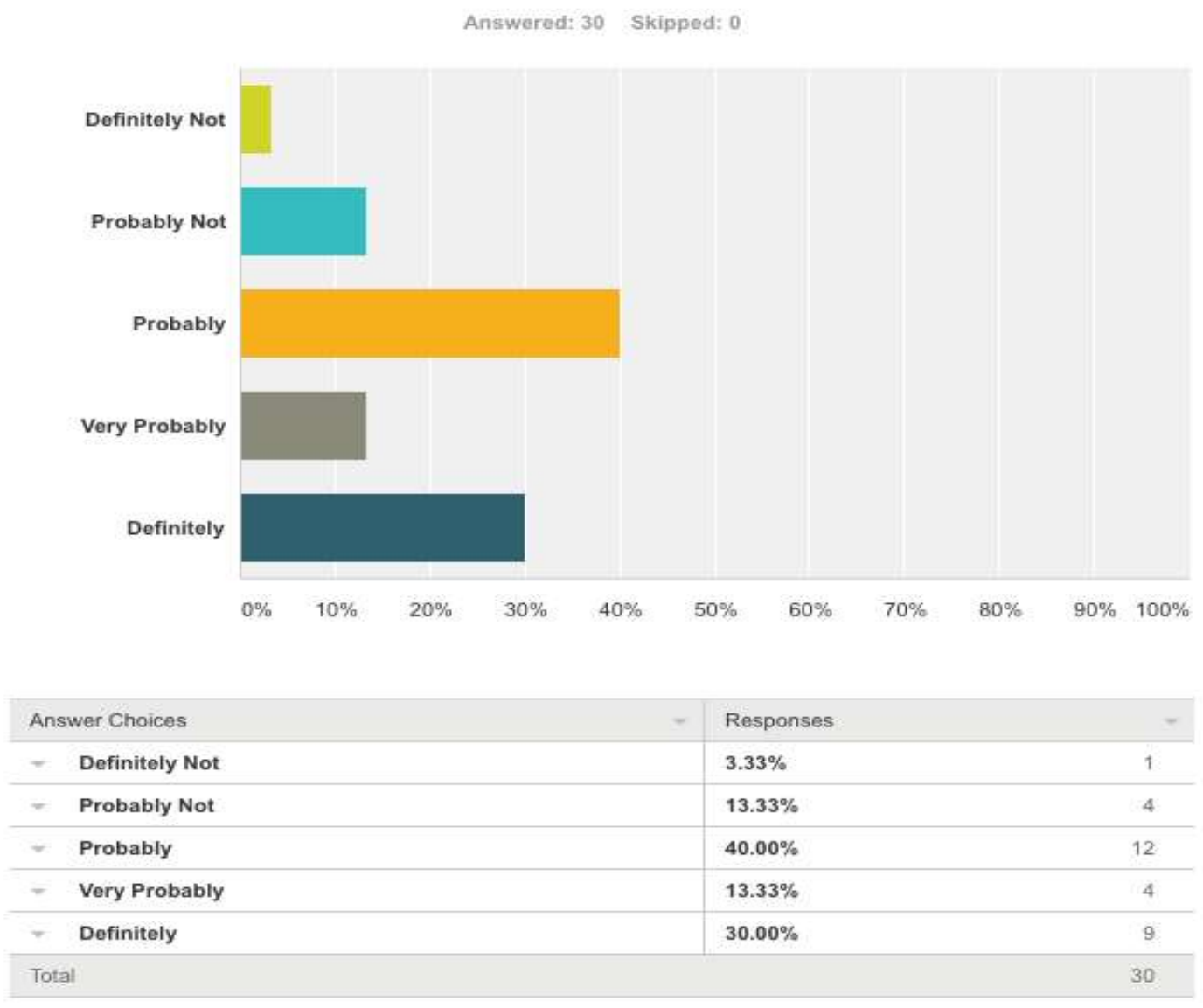

Table 1.2

Table 1.2: The table gives information about the willingness of using the mobile application in learning. On average, the respondents prefer to use mobile phones in class for the facilitation of the learning process; $30 \%$ definitely want to use the mobile application in class, meanwhile less than $14 \%$ are very probably. The highest percentage of respondents is acceptable to the idea of using their phones in learning. Nevertheless, around $16 \%$ of the respondents disagree or do not want to use the mobile in the learning process. 


\section{Do you think that using the mobile application to make better communication between you and your instructor is a good idea?}

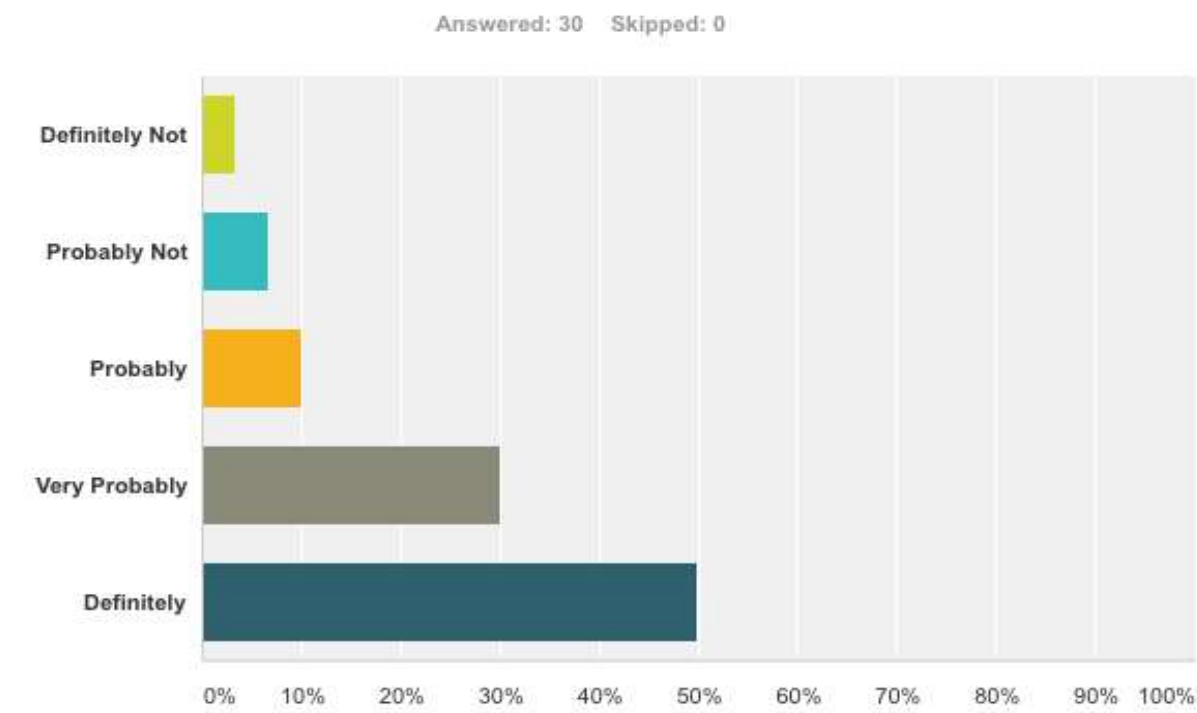

\begin{tabular}{|c|lc}
\hline Answer Choices & Responses \\
\hline Definitely Not & $3.33 \%$ & 1 \\
\hline$*$ Probably Not & $6.67 \%$ & 2 \\
\hline$*$ Probably & $10.00 \%$ & 3 \\
\hline Very Probably & $30.00 \%$ & 9 \\
\hline Definitely & $50.00 \%$ & 15 \\
\hline Total & & 30 \\
\hline
\end{tabular}

Table 1.3

Table 1.3: The table presents information about the students' opinions in considering the use of mobile application to make better communication between them and their instructors.

Interestingly, It can be seen that $50 \%$ of the students think it is a good idea to communicate with their instructors via mobile application, and less than $4 \%$ do not. Meanwhile, $30 \%$ of students claimed that they might use the application if given the opportunity from the university; this segment chose very probably. In addition, $10 \%$ chose probably and around $10 \%$ did not think it is a good idea to communicate with their instructors via mobile application. 


\section{How do you evaluate the communication with your instructor in the existing system (Blackboard) ?}

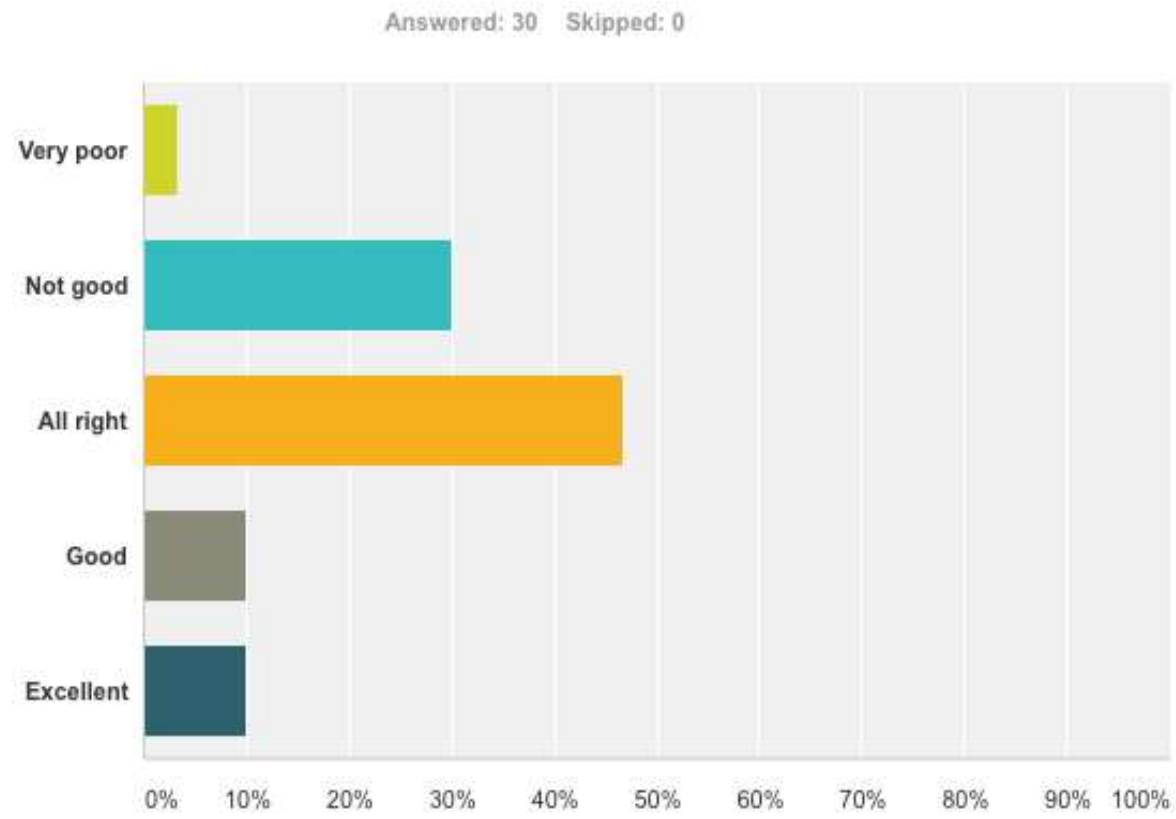

\begin{tabular}{|c|lc}
\hline Answer Choices & Responses & $>$ \\
\hline Very poor & $3.33 \%$ & 1 \\
\hline Not good & $30.00 \%$ & 9 \\
\hline All right & $46.67 \%$ & 3 \\
\hline Good & $10.00 \%$ & 3 \\
\hline Excellent & $10.00 \%$ & 30 \\
\hline Total & & 3 \\
\hline
\end{tabular}

Table 1.4

Table 1.4: To answer the question that investigates how the students evaluate the communication with their instructors with the existing system (Blackboard), the majority of respondents, less than $(50 \%)$ of students, are satisfied with the level of communication between teachers and students that occurred in the third and the fourth year. But as it is seen in the table, $30 \%$ of students feel that the communication is not good; meanwhile, $20 \%$ of the respondents think that the communication varies between good and excellent, and only $5 \%$ think it is very poor. 


\section{Do you think that using easy and professional mobile application can facilitate the communication between you and your instructor?}

Answered: 30 Skipped: 0

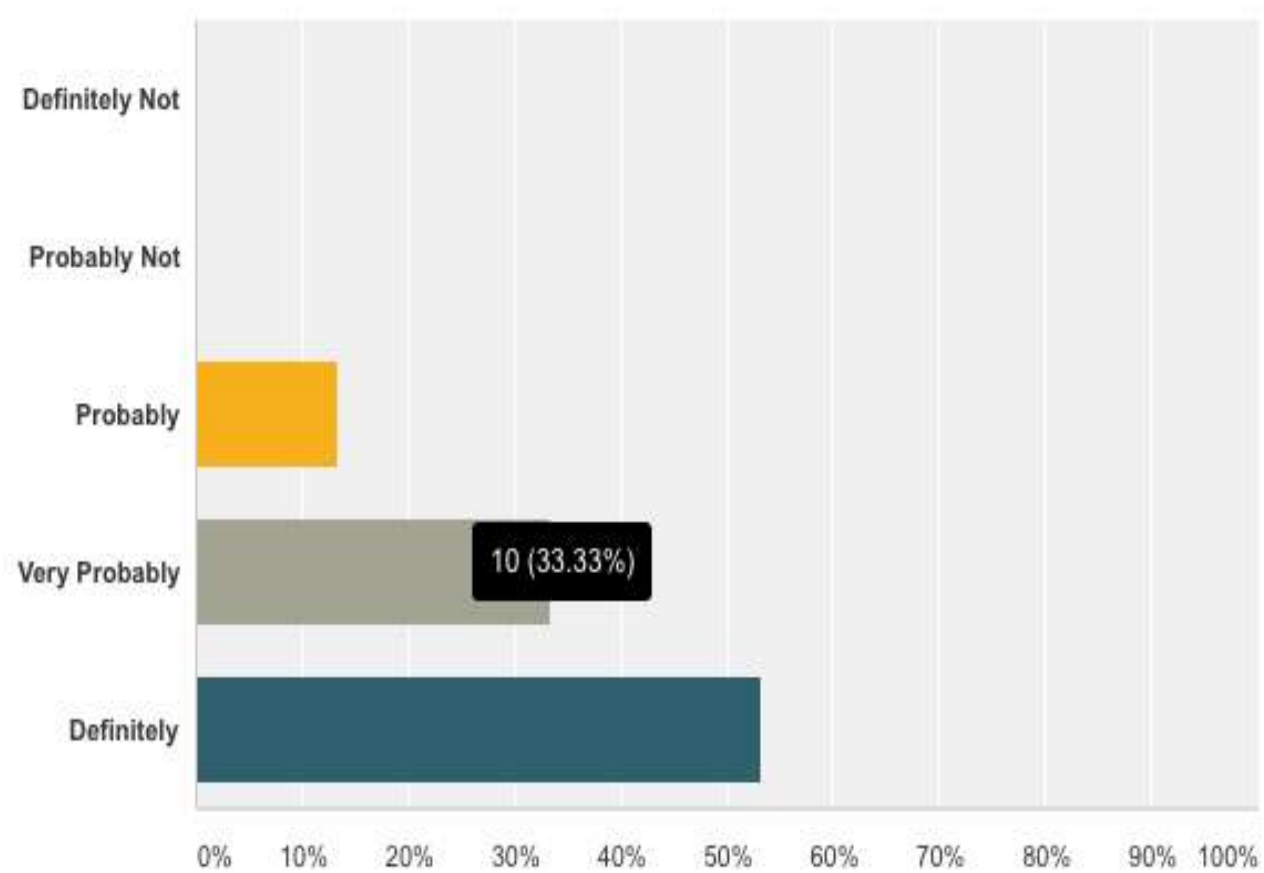

\begin{tabular}{|l|ll}
\hline Answer Choices & Responses \\
\hline Definitely Not & $0.00 \%$ & 0 \\
\hline Probably Not & $0.00 \%$ & 0 \\
\hline Probably & $13.33 \%$ & 4 \\
\hline Very Probably & $33.33 \%$ & 10 \\
\hline Definitely & $53.33 \%$ & 16 \\
\hline Total & & 30 \\
\hline
\end{tabular}

Table 1.5

In Table 1.5: overall, around of 55\% of students believed that having a professional mobile application can facilitate the communication between the students and instructor. Thus, $34 \%$ are in need of such communication, and around $12 \%$ felt encouraged to have a professional mobile application to communicate with the instructors. 


\section{Would you like to discuss your thoughts or feedback given by the instructor through a mobile application?}

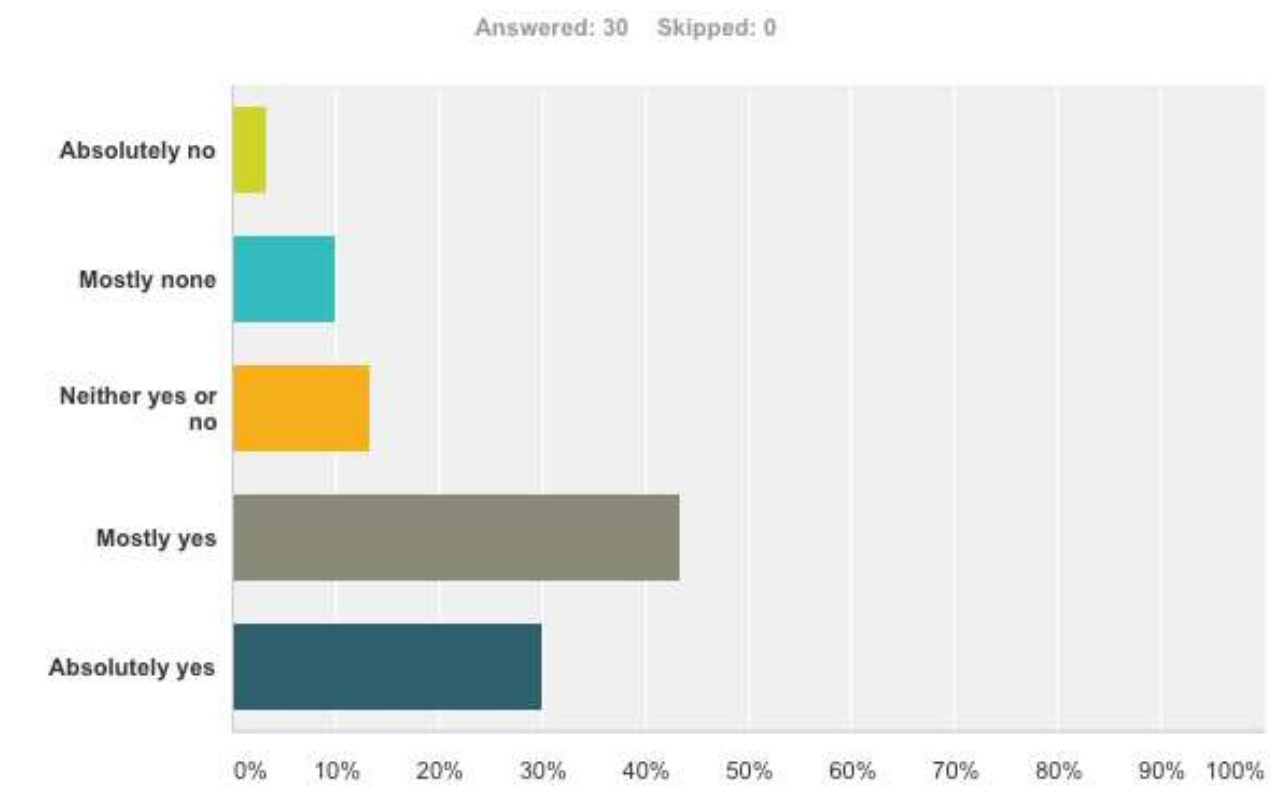

\begin{tabular}{|l|lc}
\hline Answer Choices & Responses \\
\hline$*$ Absolutely no & $3.33 \%$ & 1 \\
\hline$*$ Mostly none & $10.00 \%$ & 3 \\
\hline$*$ Neither yes or no & $13.33 \%$ & 4 \\
\hline$*$ Mostly yes & $43.33 \%$ & 13 \\
\hline Absolutely yes & $30.00 \%$ & 9 \\
\hline Total & & 30 \\
\hline
\end{tabular}

Table 1.6

As seen in Table 1.6, the majority felt comfortable to have a mobile application to discuss their thoughts or receive feedback from their instructors, and around 14\% show resistance in incorporating such technology in the learning process. On the other hand, the respondents that agreed with a percentage of absolutely yes $30 \%$ and mostly yes around $45 \%$ to the idea of receiving constant feedback from their teachers when the students are not physically in campus after the last day of classes, during the internship, and during the final exam period through mobile. 


\section{Do you have a problem in receiving constant feedback from your teachers when you are not physically in campus after the last day of classes, during the internship and during the final exam period?}

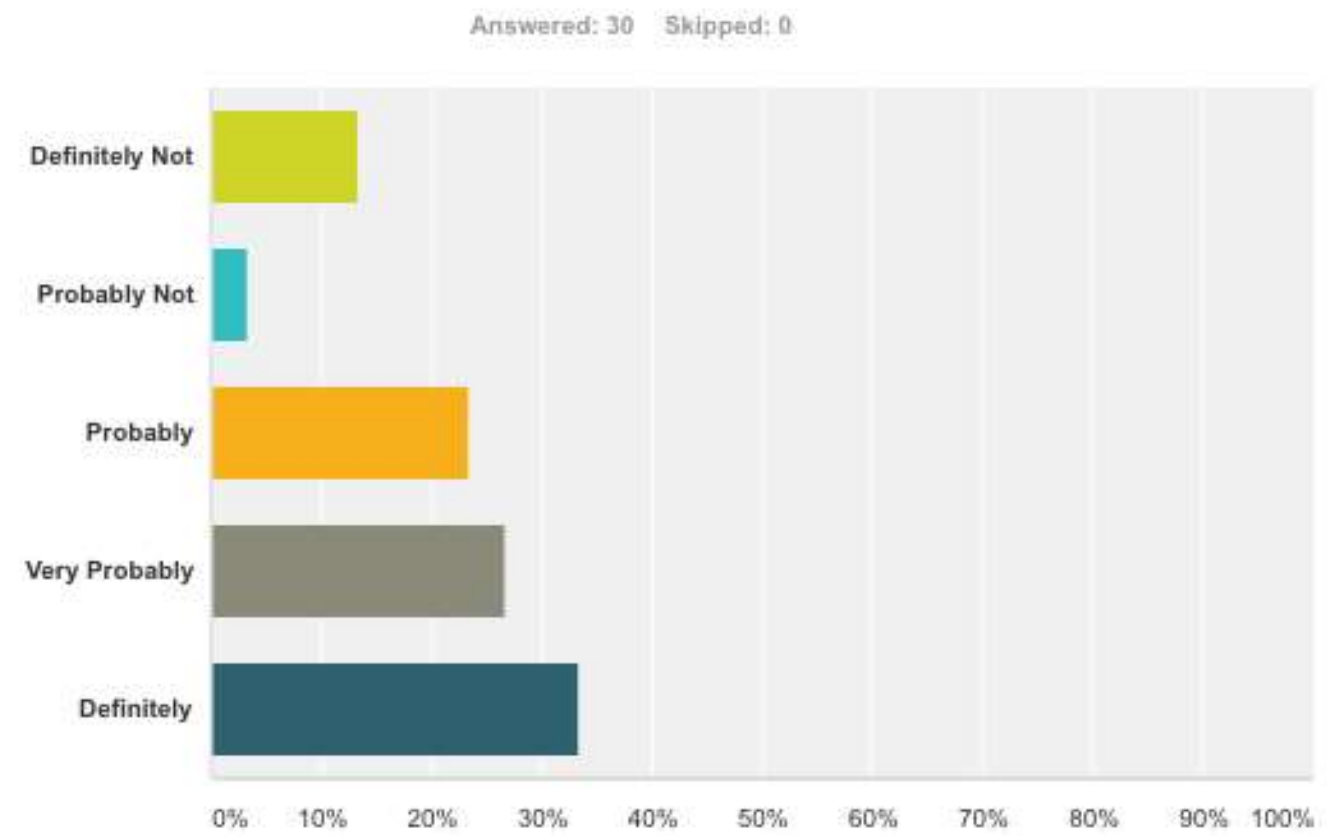

\begin{tabular}{|c|c|c|c|}
\hline \multicolumn{2}{|c|}{ Answer Choices } & \multirow{2}{*}{$\begin{array}{l}\text { Responses } \\
13.33 \%\end{array}$} & \multirow{2}{*}{4} \\
\hline$\psi$ & Definitely Not & & \\
\hline$*$ & Probably Not & $3.33 \%$ & 1 \\
\hline$*$ & Probably & $23.33 \%$ & 7 \\
\hline+ & Very Probably & $26.67 \%$ & 8 \\
\hline$*$ & Definitely & $33.33 \%$ & 10 \\
\hline \multicolumn{3}{|c|}{ Total } & 30 \\
\hline
\end{tabular}

Table 1.7

Also Table 1.7 tackles the core idea of the research when students are not physically in campus. Some students preferred to have a mobile application in which they are able to use the mobile devices as a feedback tool. Participants' opinions varied as more than $33 \%$ want to use mobile application and more than $26 \%$ choose very probably from the scale; nevertheless, around $23 \%$ students picked probably. Low respondents choose that they do not use the application as a feedback tool. 


\section{Do you think that communicating with your teacher anytime using the mobile application would allow you to resolve much of the issues when you are off campus?}

Answered: 30 Skipped: 0

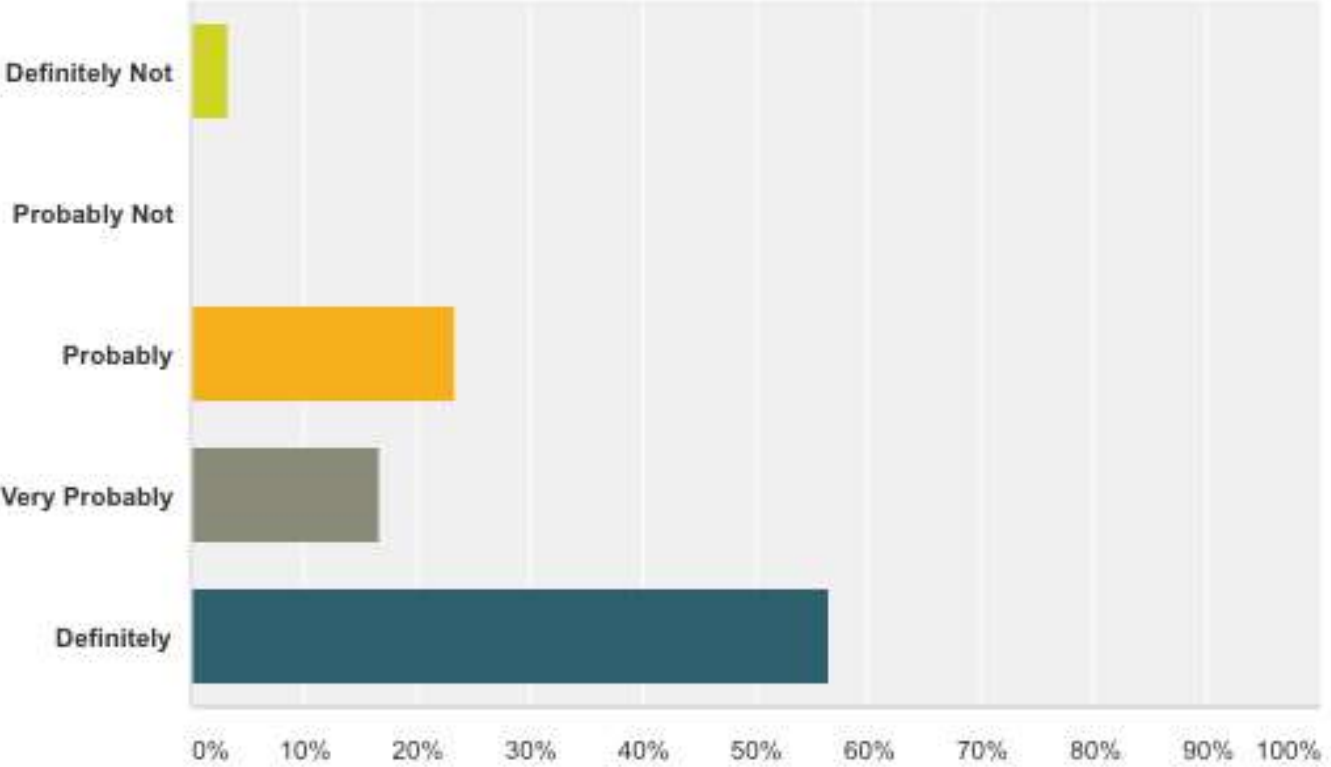

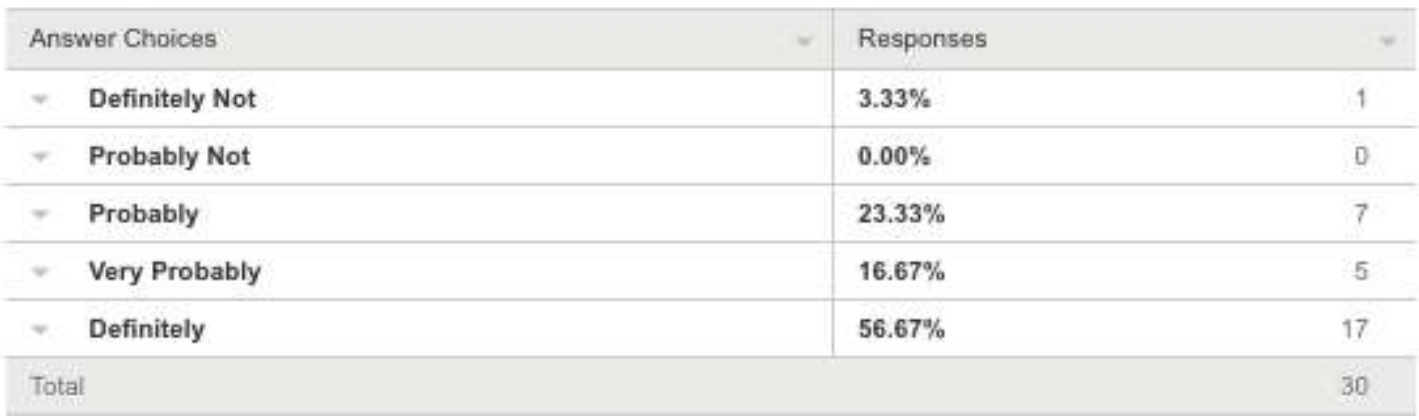

Table 1.8

Table 1.8 also supports the core idea of the research in which students agreed on using mobile application to communicate with their teacher to resolve most of the issues when they are off campus during summer internship, after the last day of classes, while printing off campus and while photo shooting. All the participants in the survey agreed on using the m-learning as a feedback tool will help in solving all the faced problems while they are off campus; around $4 \%$ only thought that using the mobile application will not help in this matter.

From the open answer questions; the authors gathered the comments as the participants mentioned brand names of mobile application that had been used as a communication tool. Whatsapp was the common application used in communication between students and their instructors; another respondent mentioned Wrike application, which is an application, designed for coworkers in big companies; others mentioned Socrative and Blackboard.

\section{ANALYZE OF THE FACULTY SURVEY}

The authors conducted a survey to sample of faculty from Dar Al-Hekma University, 12 faculty members participated in this survey, and these faculties teach sophomores and seniors students in the creative field. 
Both students and faculties responded to the same question that measures their willingness in use of mobile application to facilitate the learning process. Overall, the results indicate that teachers want to have mobile application to facilitate the learning process. In Table 2.1 the highest percentage of respondents is accepting the idea of using their phones in learning; more than $40 \%$ chose definitely. Then, the percentage decreased to reach more than $30 \%$ very probably. Less than $20 \%$ chose probably and around $10 \%$ chose not probably. These results align with the students' responses typically, and consequently we need to have such technology to communicate with students.

\section{Would you like to use mobile phone in your class for the facilitation of the learning process?}

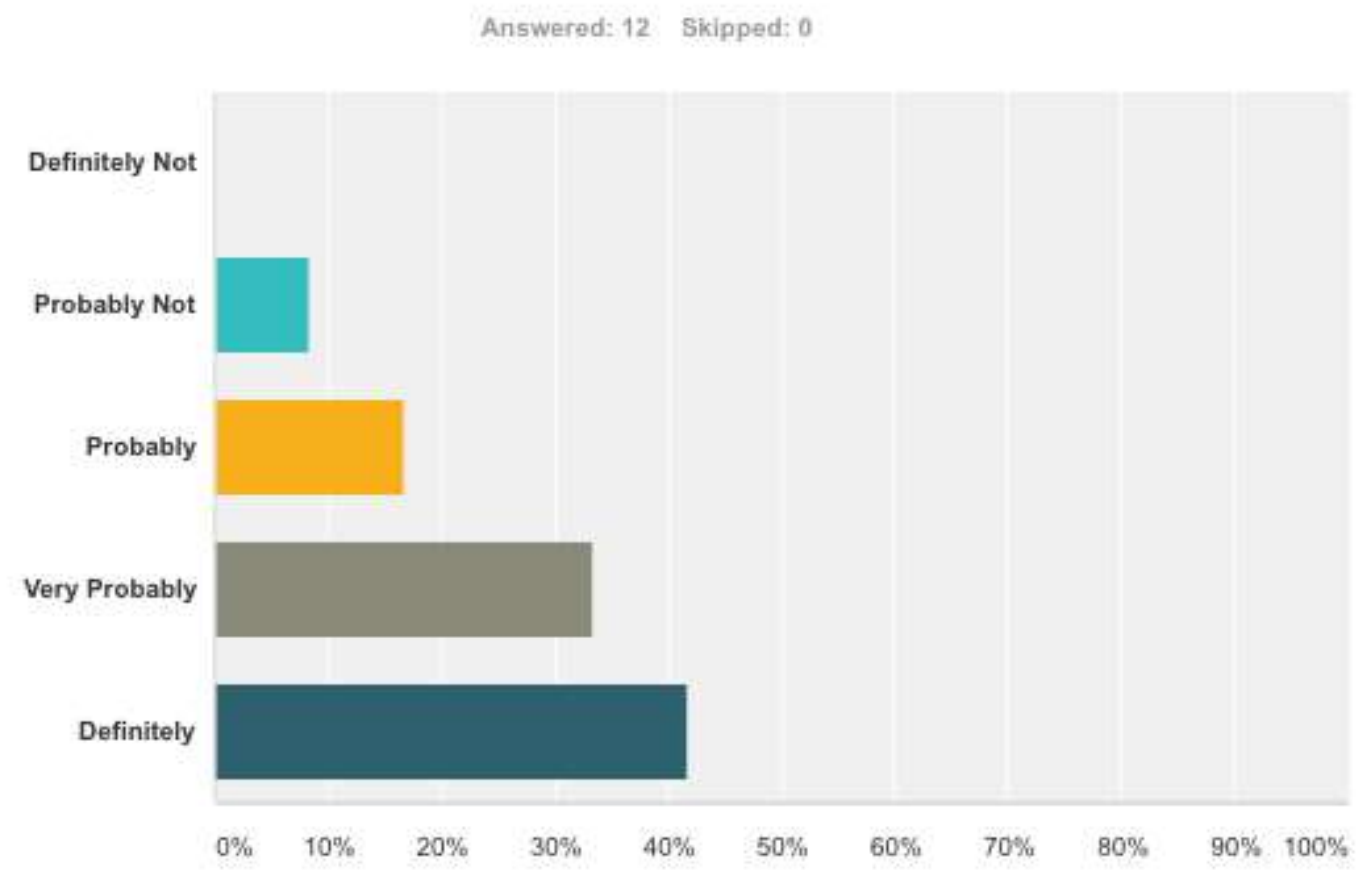

\begin{tabular}{|l|l|}
\hline Answer Choices & Responses \\
\hline Definitely Not & $0.00 \%$ \\
\hline Probably Not & $\mathbf{8 . 3 3 \%}$ \\
\hline Probably & $16.67 \%$ \\
\hline Very Probably & $33.33 \%$ \\
\hline Definitely & $\mathbf{4 1 . 6 7 \%}$ \\
\hline Total & \\
\hline
\end{tabular}

Table 2.1 


\section{Do you think that using the mobile application to make better communication between you and your students is a good idea?}

Answered: 12 Skipped: 0

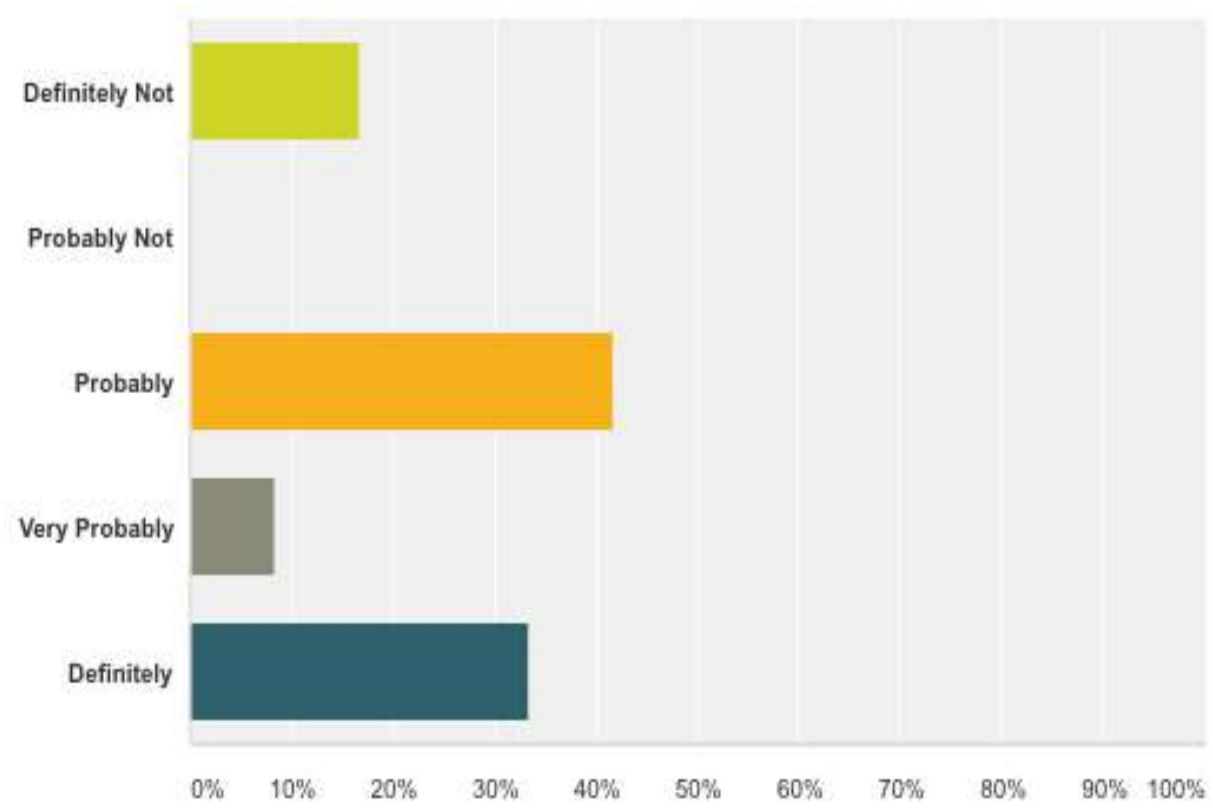

\begin{tabular}{|l|lc}
\hline Answer Choices & Responses \\
\hline Definitely Not & $16.67 \%$ & 2 \\
\hline Probably Not & $0.00 \%$ & 0 \\
\hline Probably & $41.67 \%$ & 5 \\
\hline Very Probably & $8.33 \%$ & 1 \\
\hline Definitely & $33.33 \%$ & 4 \\
\hline Total & & 12 \\
\hline
\end{tabular}

Table 2.2

In Table 2.2, it can be seen that the responses for this question varied as it is around $33 \%$ definitely, then it decreased to reach less than $9 \%$ very probably. After that, it increased to more than $41 \%$ probably. Last, around $16 \%$ dislike to have a mobile application to communicate with their students. 


\section{Do you think that interests of students to participate in class could be increased if they are using the mobile devices?}

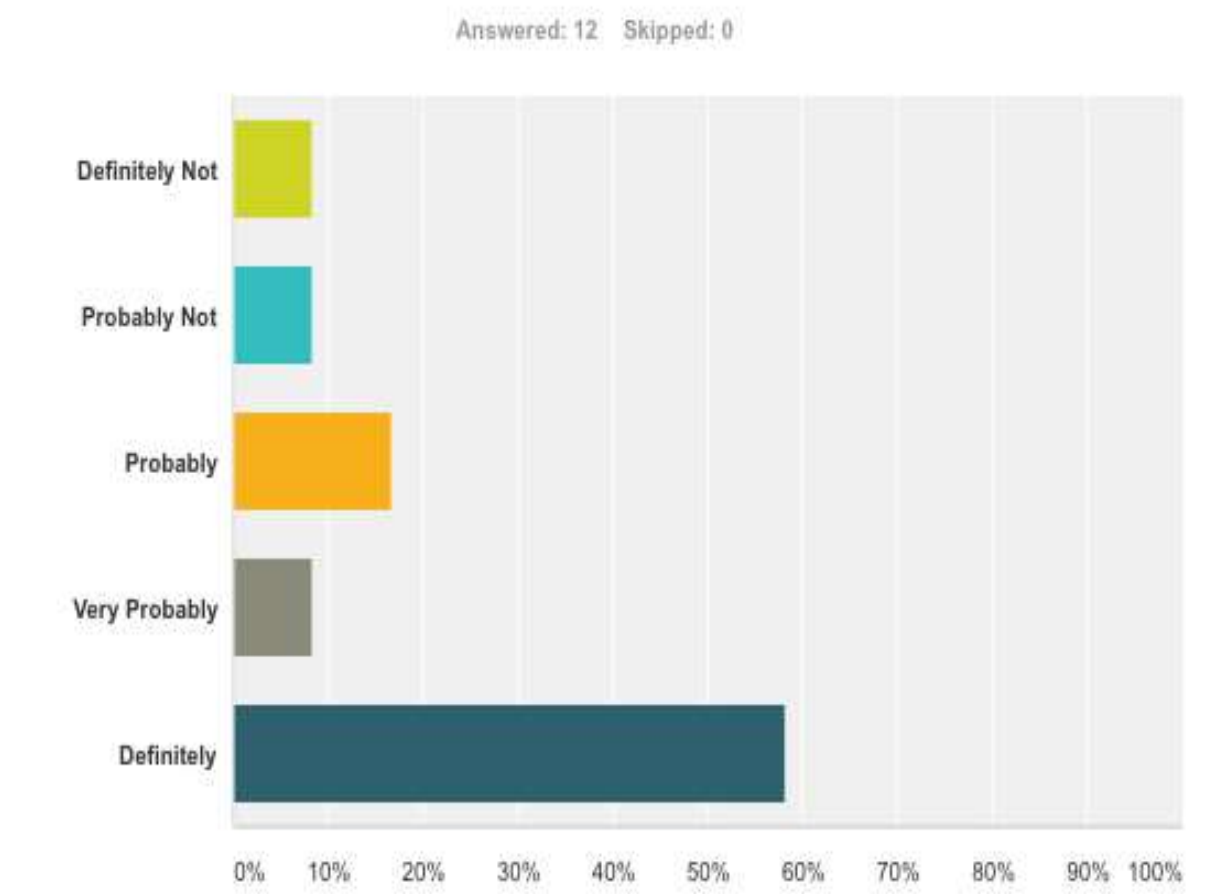

\begin{tabular}{|l|lc}
\hline Answer Choices & Responses \\
\hline Definitely Not & $8.33 \%$ & 1 \\
\hline Probably Not & $8.33 \%$ & 1 \\
\hline Probably & $16.67 \%$ & 2 \\
\hline Very Probably & $8.33 \%$ & 1 \\
\hline Definitely & $58.33 \%$ & 7 \\
\hline Totat & & 12 \\
\hline
\end{tabular}

Table 2.3

The results of Table $\mathbf{2 . 3}$ show that around $60 \%$ of teachers believe that the students' participation will increase if the university allows teachers to use mobile application in/out of the classroom; the results decrease dramatically to above $8 \%$ very probably, $16 \%$ probably, and more than $16 \%$ do not think it is a good idea to use mobile application to communicate with students. 


\section{Do you think such technology could help you out to communicate with the students even when you are off campus, after last day of classes and exam week?}

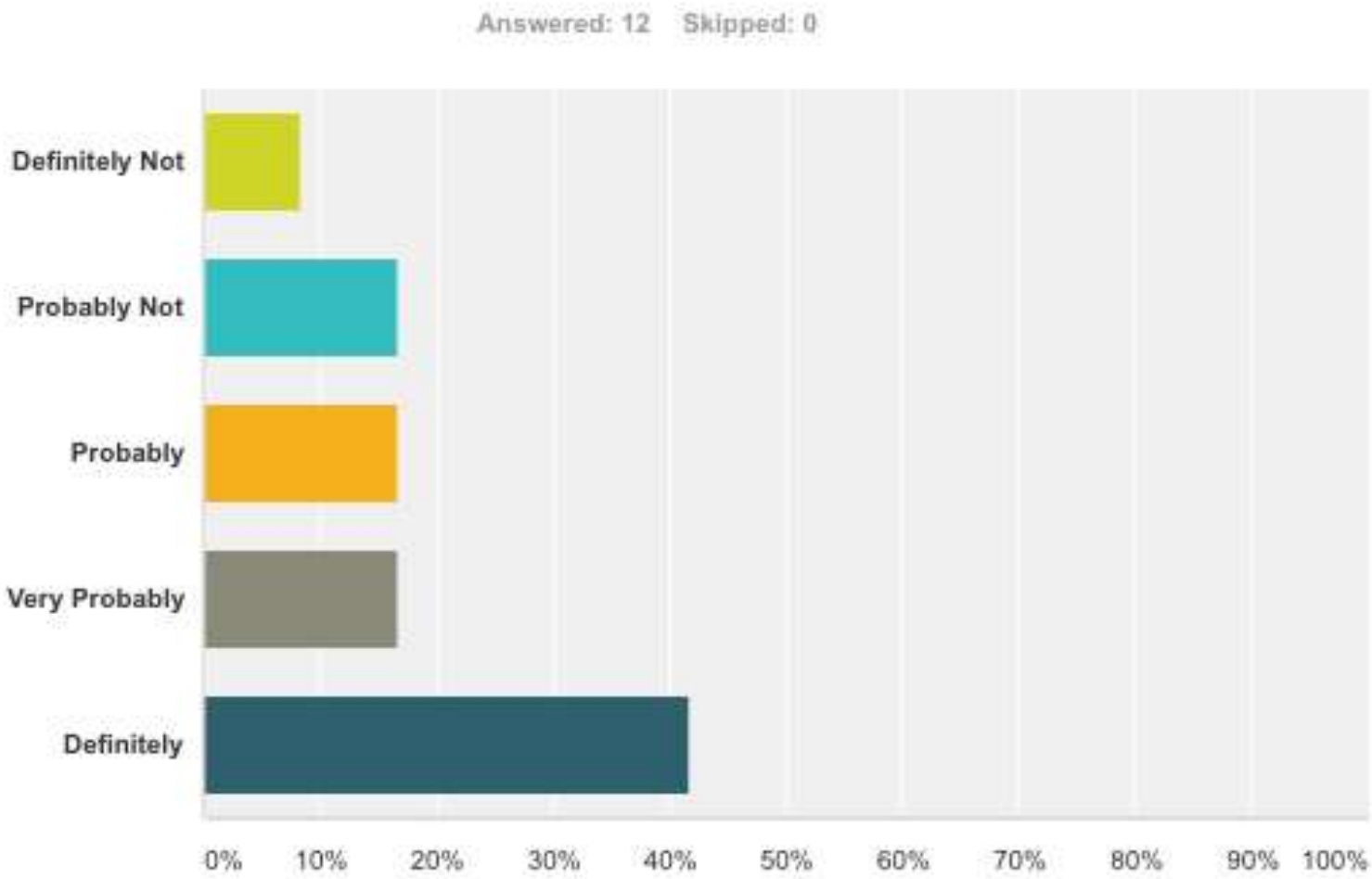

\begin{tabular}{|l|lc}
\hline Answer Choices & Responses & \\
\hline Definitely Not & $\mathbf{8 . 3 3 \%}$ & 1 \\
\hline Probably Not & $16.67 \%$ & 2 \\
\hline Probably & $16.67 \%$ & 2 \\
\hline$\quad$ Very Probably & $16.67 \%$ & 2 \\
\hline Definitely & $41.67 \%$ & 5 \\
\hline Total & & 12 \\
\hline
\end{tabular}

Table 2.4

Table 2.4 shows that faculty wants to use the mobile application in learning, but only more than $40 \%$ want to use it to communicate with students off campus, and it decreases to around $17 \%$ very probably and $17 \%$ probably. Also, around $17 \%$ chose probably not. Only $8 \%$ chose definitely not as they thought it is not a good idea to use mobile application to communicate with students while they are off campus after the last day of classes, while photo shooting outside the campus and during the internship. 


\section{Do you think that communicating with your students anytime using the mobile application would allow you to resolve much of the issues when you are off campus?}

Answered: 12 Skipped: 0

Definitely Not

Probably Not

Probably
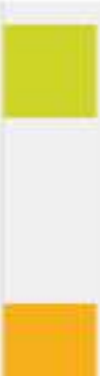

Very Probably

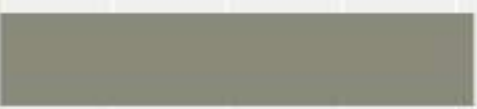

Definitely
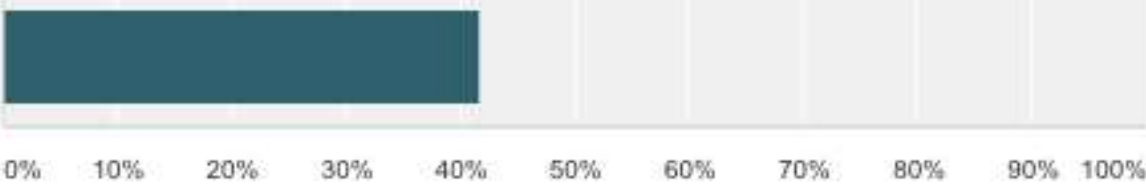

\begin{tabular}{|c|l|}
\hline Answer Choices & Responses \\
\hline Definitely Not & $\mathbf{8 . 3 3 \%}$ \\
\hline Probably Not & $0.00 \%$ \\
\hline Probably & $\mathbf{8 . 3 3 \%}$ \\
\hline Very Probably & $\mathbf{4 1 . 6 7 \%}$ \\
\hline Definitely & $41.67 \%$ \\
\hline Total & \\
\hline
\end{tabular}

Table 2.5

In Table 2.5, the teachers prove that they need a mean to communicate with students to resolve a lot of issues that students face off campus. Around $41 \%$ definitely and $41 \%$ very definitely think that they need $\mathrm{m}$ learning to communicate with students. Less than $10 \%$ choose probably, and the same amount of responses for definitely not. 


\section{Do you have a problem in giving constant feedback to your students when they are off campus specially after the last day of classes and during the final exam period?}

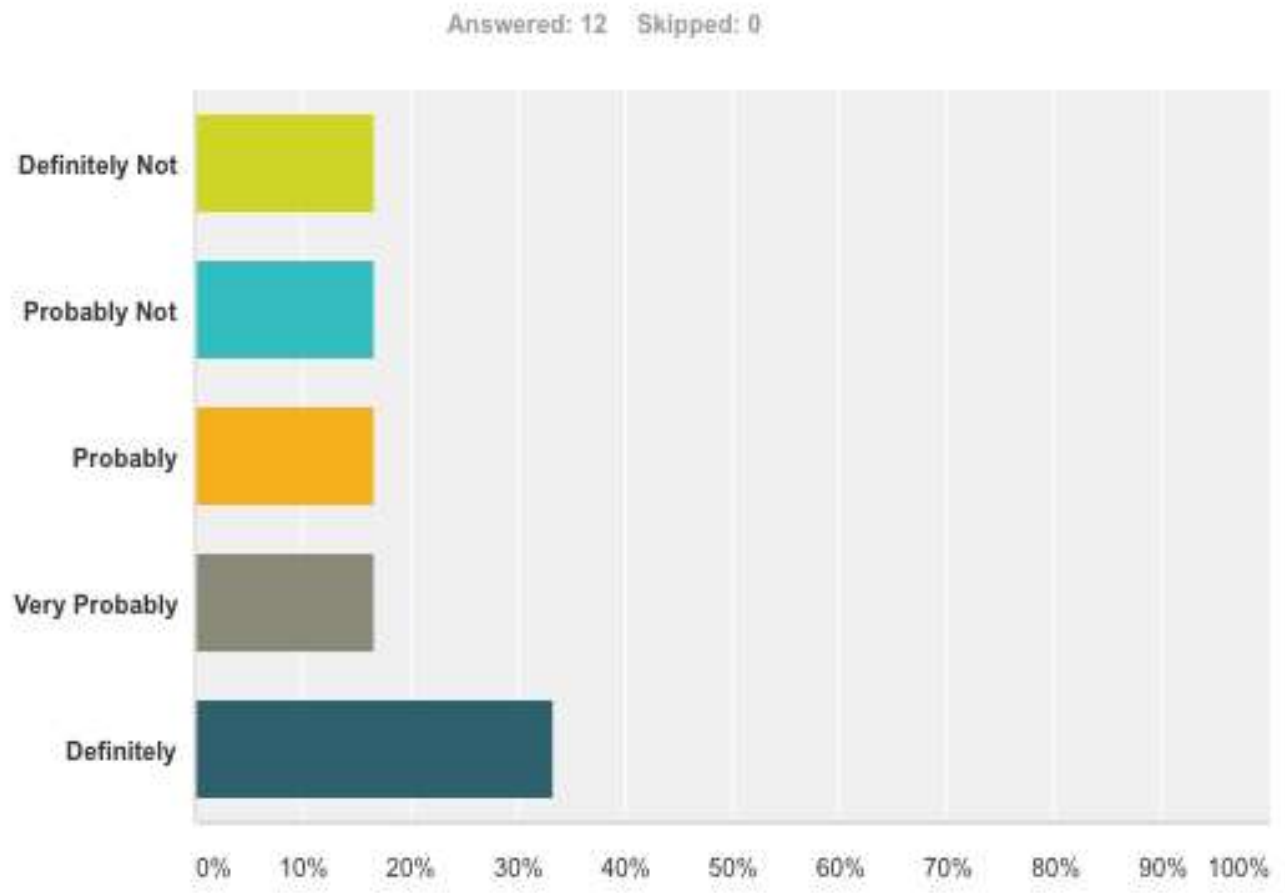

\begin{tabular}{|l|ll}
\hline Answer Choices & Responses & \\
\hline Definitely Not & $16.67 \%$ & 2 \\
\hline Probably Not & $16.67 \%$ & 2 \\
\hline Probably & $16.67 \%$ & 2 \\
\hline Very Probably & $16.67 \%$ & 2 \\
\hline Definitely & $33.33 \%$ & 4 \\
\hline Total & & 12 \\
\hline
\end{tabular}

Table 2.6

Table 2.6 measures the fact of the need to have a mobile application to communicate with students, and it also supports the core idea of the research about resolving the faced issues when they are off campus. More than $33 \%$ definitely and more than $16 \%$ very probably admitted that they are facing a problem in giving feedback to students while they are off campus; meanwhile, more than $16 \%$ probably, more than $16 \%$ probably not, and around $16 \%$ thought that using the mobile application will not help in this matter. 


\section{Would you like to get trained regarding the m-learning method to make the effective use of such applications?}

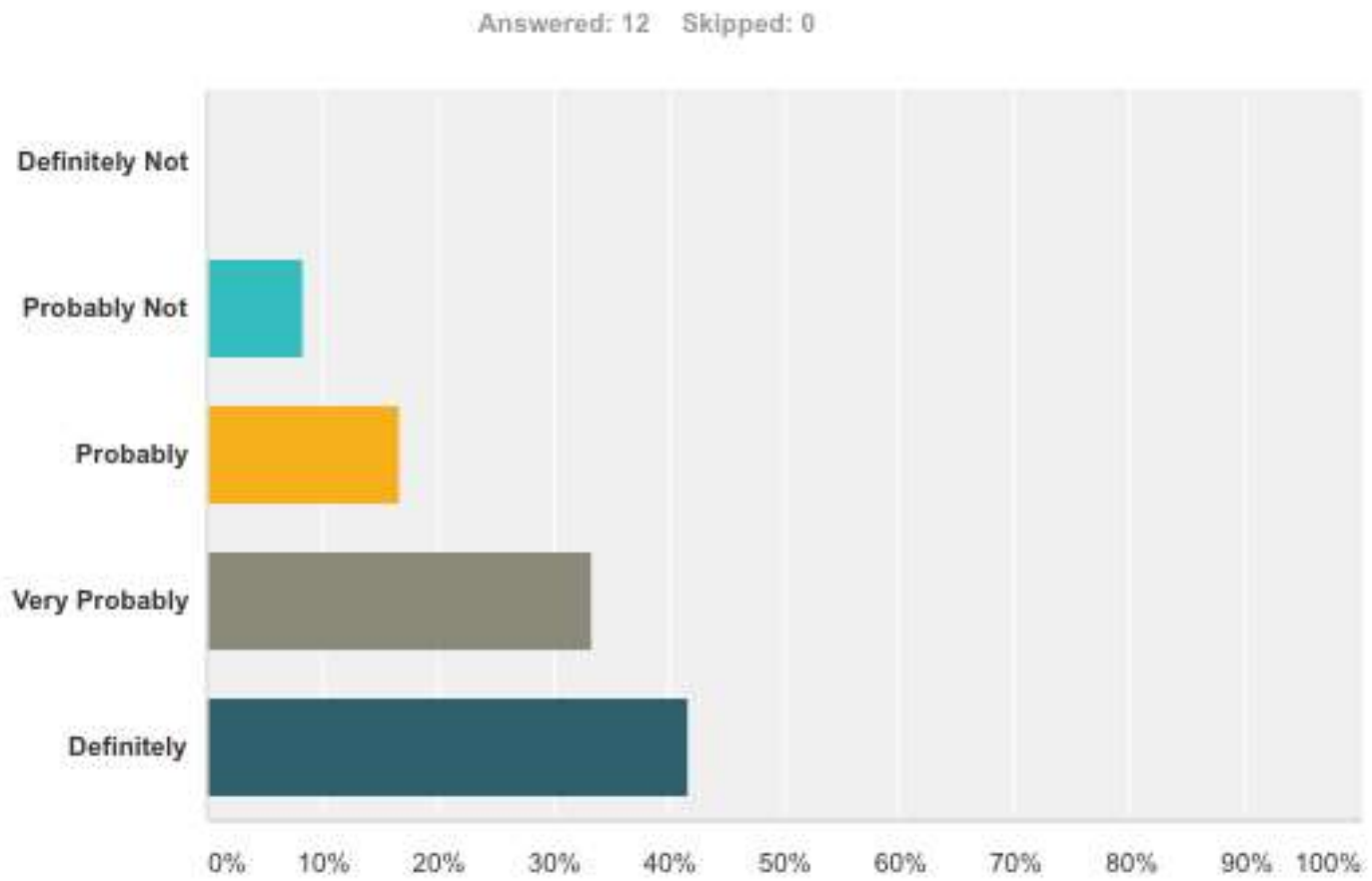

\begin{tabular}{|l|l|}
\hline Answer Choices & Responses \\
\hline Definitely Not & $\mathbf{0 . 0 0 \%}$ \\
\hline Probably Not & $\mathbf{8 . 3 3 \%}$ \\
\hline Probably & $\mathbf{1 6 . 6 7 \%}$ \\
\hline Very Probably & $33.33 \%$ \\
\hline Definitely & $\mathbf{4 1 . 6 7 \%}$ \\
\hline Total & \\
\hline
\end{tabular}

Table 2.7

Table 2.7 shows that $40 \%$ definitely need to get trained regarding the m-learning approach. Also, more than $30 \%$ very probably want to get trained. The percentage decreases to reach less than $20 \%$ probably and less than $10 \%$ probably not. 


\section{What kind of features you would like to see in such mobile application?}

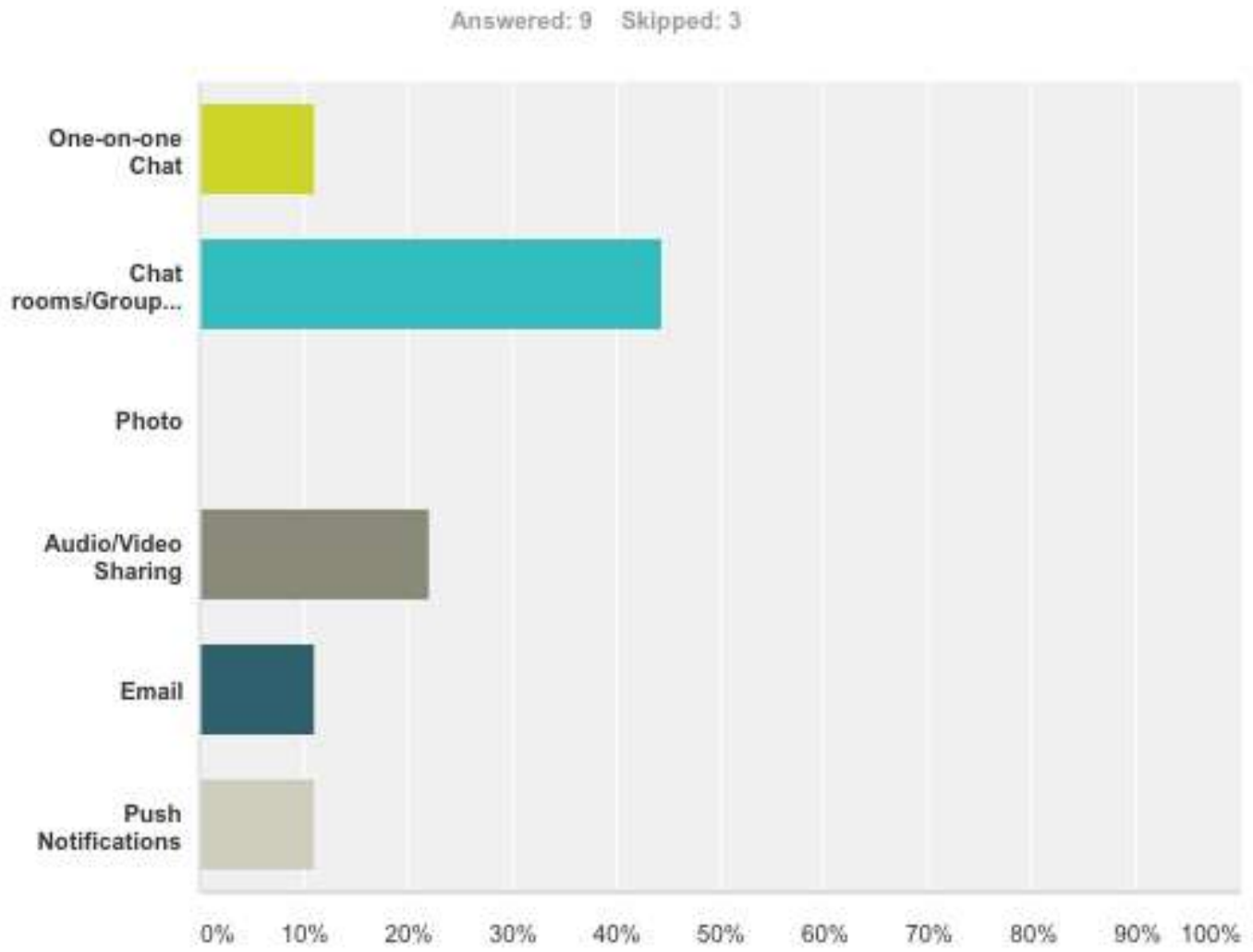

\begin{tabular}{|l|lc}
\hline Answer Choices & Responses \\
\hline$*$ One-on-one Chat & $11.11 \%$ & 1 \\
\hline Chat rooms/Group Chat & $44.44 \%$ & 4 \\
\hline Photo & $0.00 \%$ & 0 \\
\hline Audio/Video Sharing & $22.22 \%$ & 2 \\
\hline Email & $11.11 \%$ & 1 \\
\hline Push Notifications & $11.11 \%$ & 1 \\
\hline Total & & 9 \\
\hline
\end{tabular}

Table 2.8

Table 2.8 shows that most faculties prefer to have a chat room group (44\%) as the most needed feature in mobile application in the learning process. Second, they chose audio/video sharing. Last, the same percentage $(11 \%)$ was given to one-on-one chat, email, and push notifications. The results explain the willingness of the faculties wanting to communicate with their students while they are off campus. They can give feedback as a group, give instructions, and solve learning related issues.

\section{DATA ANALYSIS OF OPEN-ENDED SURVEY RESPONSES}

The researchers employed a survey to obtain qualitative data through open-ended questions. One of these questions was asking the faculty members if they know/use any mobile application to communicate with students, and, from the faculty responses, they said that they use WhatsApp to communicate with students. Also, they suggested other application brand names. 


\section{FINDINGS, SURVEY ANALYSIS}

"The effectiveness of M-learning as a feedback tool in higher education", promotes Internet-based informal collaboration over learning mobile application by exploring the plausibility of providing effective and professional learning experience services to students in the creative field, facilitates the collaboration between the teacher and student, and enhances the learning experience off campus.

- Both students and faculty want use the mobile in the learning process in Dar Al-Hekma University to resolve the faced problem while students are off campus.

- The faculties want to receive training for the use of communication and the feedback tool that could be part of their professional plan.

- Some of the survey questions show that faculties want to use the mobile application in learning, but there are some of faculty members that may be hesitant in using it while student are off campus.

- Out of the survey, some faculties admitted that they are facing a problem in giving feedback to students while they are off campus; meanwhile, a small percentage thought that using the mobile application will not help in this matter.

- Based on literature review of previous researches done about using technology and mobile learning in higher education, the authors think that Dar Al-Hekma University needs to cope with or take advantage of the m-learning.

- We completed the analysis between the data collected from the survey distributed in 2016. We highlighted the key developments in mobile practice, although the two surveys (faculty and students) were not identical; we compared similar items to evaluate changes in data in specific situations and for certain level of students.

\section{CONCLUSIONS AND RECOMMENDATIONS}

Since mobile learning is spreading rapidly and probably becoming one of the most efficient ways of delivering higher education instruction in the future, it has become necessary to examine its consequences for the use of mobile learning in the Arab world and specifically in Dar Al-Hekma University and study the effects of culture on using such technology in learning and its use in different contexts or disciplines.

Investigate and explore the practice of this particular medium in terms of the feasibility and satisfaction for both faculty and students. Then study this in society at large scale.

The authors suggest to study the academic apps students and faculty reported using regularly included university apps (Blackboard) and apps for education (such as Quizlet, Flashcards, Pearson, Evernote, Aldiko book reader, Tegrity, CourseSmart, Evernote Dropbox, Keynote Notes and Kahoot Socrative. and Duolingo)

Dar Al-Hekma University does not consider WhatsApp as a professional tool to communicate with students, but the research shows that most of the faculties use WhatsApp as a communication tool with students. The authors will investigate and study the effectiveness of using the mentioned applications as a professional feedback tool in the future. Also the university needs to pay for the Blackboard mobile application to be used effectively.

\section{APPENDIX}

\section{Dear Student,}

You are invited to participate in a research study titled "Exploring the effectiveness of M-learning as a feedback tool in higher education". Dr. Karima Hussein \& Madiha Rana from the Department of Visual Communication at Dar Al-Hekma University are conducting this study. The purpose of this study is to investigate using the mobile as a feedback tool in the creative field especially after the last day of classes till the submission day. Also enhancing the quality of learning and teaching in general to meet students' expectation and improve access to learning for students off campus.

In this study, you will be asked to complete a paper survey. The survey collects no identifying information of any respondent. All the respondents in the survey remain anonymous. 
There are no risks associated with participating in this study; your participation is voluntary and you are free to withdraw at any time. By completing and submitting this survey, you are indicating your consent to participate in the study. If you have any questions regarding the survey or this research project in general, please contact Dr. Karima Hussein, Email: khussein@dah.edu.sa,

Ms. Madiha Rana, Email: mrana@dah.edu.sa

Thank you for your time and your input.

Researcher's Name:

\begin{tabular}{|l|l|}
\hline Dr. Karima Hussein & Ms. Madiha Rana \\
Assistant Professor, & Lecture, \\
Visual Communication Department & Visual Communication Department \\
Dar Al-Hekma University & Dar Al-Hekma University \\
\hline
\end{tabular}

Department: Visual Communication

University: Dar Al-Hekma University

\section{SURVEY QUESTIONNAIRE FOR STUDENTS}

Note: You are requested to fill the following survey form. The information used would not be passed to anyone.

Do you use the Blackboard application?

Yes

No

If yes, please specify the features that you use

Q:1) Would you like to use mobile phone in your class for the facilitation of the learning process?
a) Definitely Not
b) Probably Not
c) Probably
d) Very Probably
e) Definitely

Q:2) Do you think that using the mobile application to make better communication between you and your instructor is a good idea?
a) Definitely Not
b) Probably Not
c) Probably
d) Very Probably
e) Definitely

Q:3) How do you evaluate the communication with your instructor in the existing system (Blackboard) ?
a) Very poor
b) Not good
c) All right
d) Good
e) Excellent 
Q:4) Do you think that using easy and professional mobile application can facilitate the communication between you and your instructor?
a) Definitely Not
b) Probably Not
c) Probably
d) Very Probably
e) Definitely

Q:5) Would you like to discuss your thoughts or feedback given by the instructor through a mobile application?
a) Absolutely no
b) Mostly none
c) Neither yes or no
d) Mostly yes
e) Absolutely yes

Q:6) Do you have a problem in receiving constant feedback from your teachers when you are not physically in campus after the last day of classes and during the final exam period?
a) Definitely Not
b) Probably Not
c) Probably
d) Very Probably
e) Definitely

Q:7) Do you think that communicating with your teacher anytime using the mobile application would allow you to resolve much of the issues when you are off campus?
a) Definitely Not
b) Probably Not
c) Probably
d) Very Probably
e) Definitely

Q:8) What kind of features would you like to see in such mobile application?
a) One-on-one Chat
b) Chat rooms/Group Chat
c) Photo
d) Audio/Video Sharing
e) Email
f) Push Notifications

Others, specify

Q:9) If you know any mobile application used as a learning tool, specify below.

\section{Dear Colleague}

You are invited to participate in a research study titled "Exploring the effectiveness of M-learning as a feedback tool in higher education". Dr. Karima Hussein \& Madiha Rana from the Department of Visual Communication at Dar Al Hekma University are conducting this study. The purpose of this study is to investigate using the mobile as a feedback tool in the creative field especially after the last day of classes till 
the submission day. Also enhancing the quality of learning and teaching in general to meet students' expectation and improve access to learning for students off campus.

In this study, you will be asked to complete a paper survey. The survey collects no identifying information of any respondent. All the respondents in the survey remain anonymous.

There are no risks associated with participating in this study; your participation is voluntary and you are free to withdraw at any time.By completing and submitting this survey, you are indicating your consent to participate in the study.

If you have any questions regarding the survey or this research project in general, please contact Dr. Karima Hussein, Email: khussein@dah.edu.sa,

Ms. Madiha Rana, Email: mrana@dah.edu.sa

Thank you for your time and your input.

Researcher's Name:

Dr. Karima Hussein

Assistant Professor,

Visual Communication Department

Dar Al-Hekma University
Ms. Madiha Rana

Lecture,

Visual Communication Department

Dar Al-Hekma University

Thank you for your time and your input.

Department: Visual Communication

University: Dar Al-Hekma University

\section{SURVEY QUESTIONNAIRE FOR FACULTY}

Q:1) Would you like to use mobile phone in your class for the facilitation of the learning process?
a) Definitely Not
b) Probably Not
c) Probably
d) Very Probably
e) Definitely

Q:2) Do you think that using the mobile application to make better communication between you and your students is a good idea?
a) Definitely Not
b) Probably Not
c) Probably
d) Very Probably
e) Definitely

Q:3) Do you think that interests of students to participate in class could be increased if they are using the mobile devices?
a) Definitely Not
b) Probably Not
c) Probably
d) Very Probably 
e) Definitely

Q:4) Do you think such technology could help you out to communicate with the students even when you are off campus, after last day of classes and exam week?
a) Definitely Not
b) Probably Not
c) Probably
d) Very Probably
e) Definitely

Q:5) Do you think that communicating with your students anytime using the mobile application would allow you to resolve much of the issues when you are off campus?
a) Definitely Not
b) Probably Not
c) Probably
d) Very Probably
e) Definitely

Q:6) Do you have a problem in giving constant feedback to your students when they are off campus specially after the last day of classes and during the final exam period?
a) Definitely Not
b) Probably Not
c) Probably
d) Very Probably
e) Definitely

Q:7) Would you like to get trained regarding the m-learning method to make the effective use of such applications?
a) Definitely Not
b) Probably Not
c) Probably
d) Very Probably
e) Definitely

Q:8) What kind of features you would like to see in such mobile application?
a) One-on-one Chat
b) Chat rooms/Group Chat
c) Photo
d) Audio/Video Sharing
e) Email
f) Push Notifications

Others, specify

Q:9) If you know any mobile application used as a learning tool, specify below. 


\section{REFERENCE LIST}

Abernathy, Donna J. "Get Ready for M-Learning." Training \& Development, Feb. 2001, p. 20. Academic OneFile, Accessed 4 Apr. 2017.

Bradford, P., Porciello, M., Balkon, N., \& Backus, D. (2007). The Blackboard Learning System: The Be All and End All in Educational Instruction? Journal of Educational Technology Systems,35(3), 301-314. doi:10.2190/x137-x73I-5261-5656

Chen, H.-R., \& Huang, H.-L. (2010). User Acceptance of Mobile Knowledge Management Learning System: Design and Analysis. Educational Technology \& Society, 13 (3), 70-77.

Christie, M., \& Garrote Jurado, R. (2009). Barriers to innovation in online pedagogy. European Journal of Engineering Education, 34(3), 273-279.

El-Hussein, M. O. M., \& Cronje, J. C. (2010). Defining Mobile Learning in the Higher Education Landscape. Educational Technology \& Society,13 (3), 12-21

Gomez, S. (2007) Scroll to 'E' for Education. The Times Higher Education Supplement, 1780, 13.

Huang, Y.-M., Hwang, W.-Y., \& Chang, K.-E. (2010). Guest Editorial - Innovations in Designing Mobile Learning Applications. Educational Technology \& Society, 13 (3), 1-2.

Kinash, S., Brand, J., \& Mathew, T. (2012). Challenging mobile learning discourse through research: Student perceptions of Blackboard Mobile Learn and iPads. Australasian Journal of Educational Technology, 28(4), 639-655.

Levine, A., \& Sun, J. C. (2003). Distributed education: Summary of a six-part series. Washington, DC: American Council on Education.

Masi, A., \& Winer, L. (2005). A university-wide vision of teaching and learning with information technologies. Innovations in Education and Teaching International, 42(2), 147-155.

Sharples, M. (2000) The Design of Personal Mobile Technologies for Lifelong Learning. Computers and Education, 34, 177-193. Thornton, P. \& Houser, C. (2005)

Thornton, P., \& Houser, C. (2005). Using mobile phones in English education in Japan. Journal of Computer Assisted Learning, 21(3), 217-228.

Wagner, E. D. (2005). Enabling mobile learning. EDUCAUSE review, 40(3), 41.

Weekes, S. (2007) Don't Believe the Hype?, Training Journal, June 19 (page numbers unavailable)

Whitsed, N. (Dec 2004) Learning and Teaching. Health Information \& Libraries Journal, 21, 273-275.

Yang, S.J.H., Chen, I., \& Shao, N., (2004). Ontological enabled annotations and knowledge management for collaborative learning in a virtual learning community. Educational Technology \& Society, 7 (4), 70-81

Websites

Aagard, Bowen, \& Olesova (2010, November 3). Hotseat: Opening the Backchannel in Large Lectures.

Educause Quarterly Volume 33, Number 3, 2010. Retrieved from

http://www.educause.edu/EDUCAUSE+Quarterly/EDUCAUSEQuarterlyMagazineVolum/HotseatOpeningthe

Backchannelin/213668on Dec 3, 2010.

Berking, P., Birtwhistle, M., Gallagher, S., \& Haag, J. (2013, September). Mobile learning Survey report. Retrieved from https://adlnet.gov/adl-assets/uploads/2016/03/MOTIFSURVEYREPORT.pdf

B. (1997). Retrieved 2017, from http://www.blackboard.com/mobile-learning/index.aspx

Heirdsfield, A., Walker, S., Tambyah, M., \& Beutel, D. (2011). Blackboard As An Online Learning Environment: What Do Teacher Education Students And Staff Think?. Australian Journal of Teacher Education, 36(7). http://dx.doi.org/10.14221/ajte.2011v36n7.4

Kim, J. (2016, September 28). Why the Future of Adult Learning Is Mobile Learning. Retrieved from https://www.insidehighered.com/blogs/technology-and-learning/why-future-adult-learning-mobilelearning

Kim, D., Rueckert, D., Kim, D.-J., \& Seo, D. Students' perceptions and experiences of mobile learning. Language Learning \& Technology, 17(3), 52-73. Retrieved from 
http://lt.msu.edu/issues/october2013/kimetal.pdf Received: June 26, 2012; Accepted: April 28, 2013; Published: October 1, 2013

McConatha, D., Praul, M., \& Lynch, M. J. (2008). Mobile learning in higher education: An empirical assessment of a new educational tool. TOJET: the Turkish online journal of educational technology, 7(3), 15-21. Retrieved from http://digitalcommons.wcupa.edu/ anthrosoc_facpub/4

Pullchino, J. (2006) Mobile Learning Research Report. The E-Learning Guild. Retrieved April 28, 2007 from http://www.elearningguild.com/ 